\title{
The presence of Tregs does not preclude immunity to reinfection with Leishmania braziliensis
}

\author{
Sarah C. Falcão ${ }^{a}$, Tatiana R. de Moura ${ }^{\mathrm{a}, 1}$, Jorge Clarêncio ${ }^{\mathrm{a}}$, Cláudia Brodskyn $^{\mathrm{a}, \mathrm{b}, \mathrm{c}}$, Aldina Barral ${ }^{\mathrm{a}, \mathrm{b}, \mathrm{c}}$, \\ Camila I. de Oliveira ${ }^{\mathrm{a}, \mathrm{c}, *}$ \\ ${ }^{a}$ Centro de Pesquisas Gonçalo Moniz, Fundação Oswaldo Cruz (FIOCRUZ), Rua Waldemar Falcão, 121, Salvador, BA, Brazil \\ ${ }^{\mathrm{b}}$ Universidade Federal da Bahia, Av. Reitor Miguel Calmon, S/N, Salvador, BA, Brazil \\ ${ }^{\mathrm{c}}$ Instituto de Investigação em Imunologia, Brazil
}

\section{A R T I C L E I N F O}

\section{Article history:}

Received 13 March 2012

Received in revised form 15 May 2012

Accepted 16 May 2012

Available online 13 June 2012

\section{Keywords:}

Leishmania braziliensis

Treg

$\mathrm{CD} 4^{+} \mathrm{CD} 25^{+}$

\begin{abstract}
A B S T R A C T
Leishmania spp. cause a broad spectrum of diseases collectively known as leishmaniasis. Leishmania braziliensis is the main etiological agent of American cutaneous leishmaniasis and mucocutaneous leishmaniasis. During experimental infection with $L$. braziliensis, BALB/C mice develop an adaptive immune response that is associated with lesion healing and, in parallel, parasite persistence within draining lymph nodes (dLNs). In the Leishmania major model of cutaneous leishmaniasis, regulatory T cells (Tregs) play an important role in immune regulation, preventing pathological immune responses but at the same time precluding sterile cure. In this study we investigated the role of Tregs during experimental infection with $L$. braziliensis. $\mathrm{CD} 4^{+} \mathrm{CD} 25^{+} \mathrm{T}$ cells were detected throughout the duration of clinical disease both at the ear and in dLNs of infected mice. These cells expressed Treg markers such as glucocorticoid-induced TNF-receptor-related protein (GITR), the $\alpha$ chain of the $\alpha \varepsilon \beta 7$ integrin (CD103), and the forkhead/winged helix transcription factor, Foxp3, and were able to suppress the proliferation of $\mathrm{CD} 4^{+} \mathrm{CD} 25^{-}$cells. Importantly, a high frequency of Foxp $3^{+}$cells accumulated at the site of infection and in dLNs. We next investigated the outcome of a reinfection with $L$. braziliensis in terms of Treg distribution and disease reactivation. Interestingly, a secondary inoculation with $L$. braziliensis did not preclude an efficient recall response to $L$. braziliensis at a distal site, despite the presence of Tregs. Within dLNs, reinfection did not promote parasite dissemination or a differential recruitment of either $\mathrm{CD} 4^{+} \mathrm{CD} 25^{+} \mathrm{Foxp} 3^{+}$or $\mathrm{CD} 4^{+} \mathrm{IL}-10^{+} \mathrm{T}$ cells. On the contrary, parasites were mainly detected in the LN draining the primary infection site where a high frequency of $\mathrm{CD} 4^{+} \mathrm{IFN}-\gamma^{+} \mathrm{T}$ cells was also present. Collectively these data show that during experimental infection, Tregs are present in healed mice but this population does not compromise an effective immune response upon reinfection with $L$. braziliensis.
\end{abstract}

(c) 2012 Australian Society for Parasitology Inc. Published by Elsevier Ltd. All rights reserved.

\section{Introduction}

The leishmaniases represent endemic infections that occur predominantly in tropical and subtropical regions. This group of diseases is characterized by symptoms that range from localized cutaneous lesions to mucocutaneous tissue destruction and the frequently fatal visceral form. Cutaneous leishmaniasis (CL) caused by Leishmania braziliensis is distinguished from other forms of leishmaniasis by its chronicity, latency and tendency to metastasize in the human host (Bittencourt and Barral-Netto, 1995). In human $\mathrm{CL}$ caused by L. braziliensis, accumulation of $\mathrm{CD} 4^{+} \mathrm{CD} 25^{+} \mathrm{T}$ cells has been observed at the infection site, indicating a role for

\footnotetext{
* Corresponding author. Tel.: +55 713176 2211; fax: +55 7131762279.

E-mail address: camila@bahia.fiocruz.br (C.I. de Oliveira).

1 Present address: Universidade Federal de Sergipe, Rua Claudio Batista, s/n, Sanatorio CEP: 49060-100 - Aracaju, Sergipe, Brazil.
}

these cells in controlling the immune response (Campanelli et al., 2006). Patients maintain $L$. braziliensis-specific immune responses after lesion healing (Ramirez and Guevara, 1997; Coutinho et al., 2002). In parallel, Leishmania persistence in the vertebrate host is referred to as concomitant immunity, and in experimental Leishmania major infections this persistence was associated with regulatory $\mathrm{CD}^{+} \mathrm{CD} 25^{+} \mathrm{T}$ cells (Tregs) (Belkaid et al., 2002).

Two main subsets of Tregs have been defined: naturally occurring $\mathrm{CD} 4^{+} \mathrm{CD} 25^{+}$Tregs, which originate in the thymus during ontogeny, and inducible Tregs, which develop in the periphery from conventional $\mathrm{CD} 4^{+} \mathrm{T}$ cells (Belkaid et al., 2006b). Naturally occurring $\mathrm{CD} 4^{+} \mathrm{CD} 25^{+}$Tregs were originally described as a population of $\mathrm{CD} 4^{+} \mathrm{T}$ cells that prevent the expansion of self-reactive lymphocytes and, therefore, autoimmune disease in mice (Sakaguchi et al., 1995). This population can be defined by their constitutive expression of the IL-2 receptor $\alpha$ chain (CD25), the cytotoxic T lymphocyte antigen (CTLA4), the TNF receptor family member GITR 

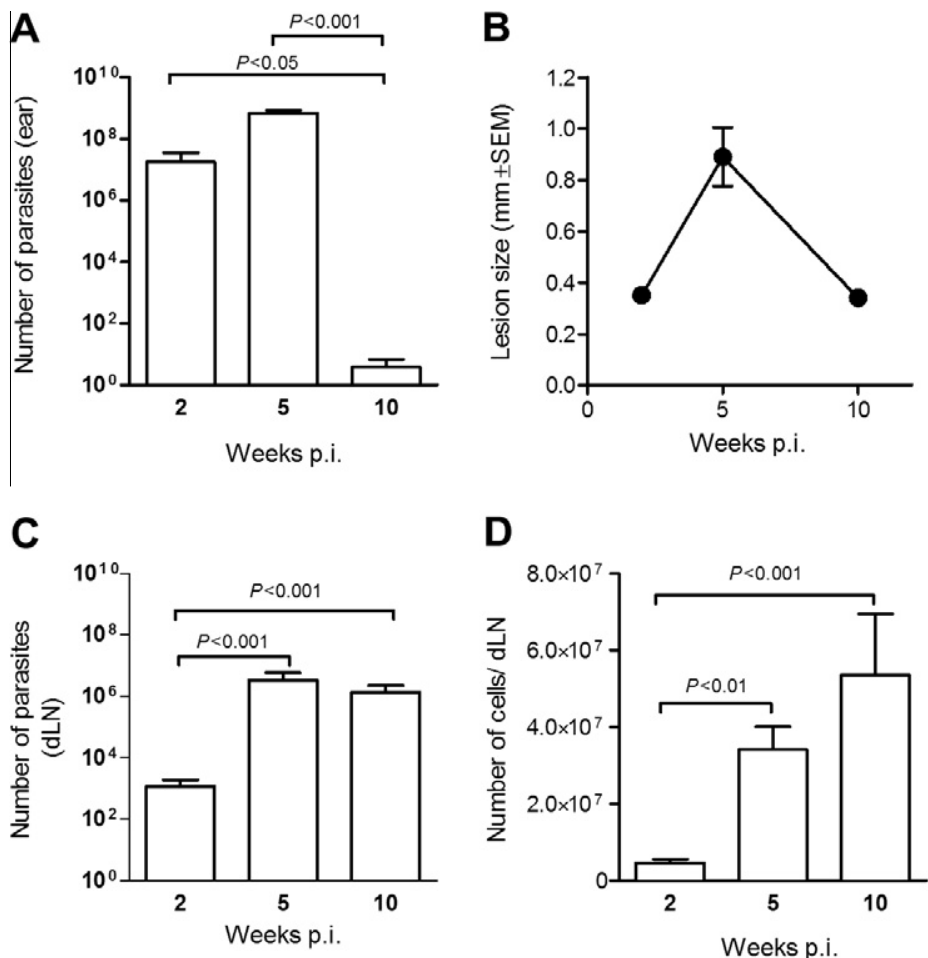

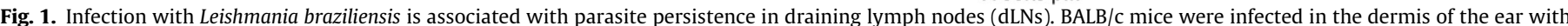

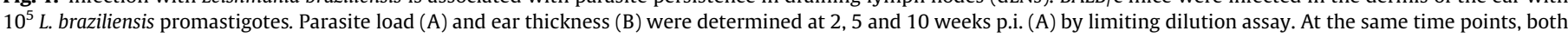

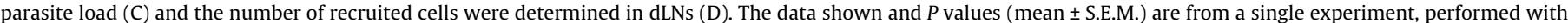
six mice, representative of three independent experiments that provided similar results.

(glucocorticoid-induced TNF-receptor-related protein), and the $\alpha$ chain of the $\alpha \varepsilon \beta 7$ integrin (CD103) (reviewed in Belkaid, 2003). Expression of these markers, however, is not specific to Tregs. In contrast, the forkhead/winged helix transcription factor Foxp3 is thought to program the development and function of Tregs and is specifically expressed in natural Tregs in mice, as well as in $\mathrm{CD}^{-} 5^{-} \mathrm{T}$ cells with regulatory activity (Fontenot et al., 2003; Hori et al., 2003; Khattri et al., 2003).

Treg-mediated suppression occurs through different mechanisms of action, both in vitro and in vivo. These include CTLA4 expression (Takahashi et al., 2000), IL-2 consumption (Pandiyan et al., 2007) and IL-35 secretion (Collison et al., 2007). Tregs have been shown to mediate suppression of effector T cells through direct contact in vitro (Piccirillo and Shevach, 2001) and through delivery of cAMP, a potent immunosuppressive compound (Bopp et al., 2007). Furthermore, suppressive cytokines may also be directly responsible for the regulatory functions of Tregs. In this sense, neutralization of IL-10 or TGF- $\beta$ abolishes Treg suppression in mouse models of inflammatory bowel disease, type 1 diabetes, transplantation and cancer (Tang and Bluestone, 2008).

In $\mathrm{CL}$, active disease is associated with a parasite-specific, cellmediated immune response in which $\mathrm{CD} 4^{+} \mathrm{T}$ cells are essential for macrophage activation through IFN $-\gamma$ production (Scott et al., 1989; Locksley et al., 1991). In mice resistant to L. major (C57BL/ 6), parasite persistence is regulated by Tregs, which control Th1 responses by both IL-10-dependent and IL-10-independent mechanisms (Belkaid et al., 2002). In L. major-susceptible BALB/c mice, in vivo depletion of $\mathrm{CD} 4^{+} \mathrm{CD} 25^{+} \mathrm{T}$ cells exacerbated the course of disease, increasing the early IL-4 burst (Aseffa et al., 2002). Transfer of $\mathrm{CD} 4^{+} \mathrm{CD} 25^{+} \mathrm{T}$ cells suppressed disease development upon $L$. major infection of severe combined immunodeficiency (SCID) mice that received naive $\mathrm{CD} 4^{+} \mathrm{CD} 25^{-} \mathrm{T}$ cells (Xu et al., 2003). In experimental Leishmania amazonensis infection, which does not lead to a polarized Th2 response, IL-10 producing $\mathrm{CD} 4^{+} \mathrm{CD} 25^{+} \mathrm{T}$ cells suppressed proliferation of $\mathrm{CD}^{+} \mathrm{CD} 25^{-}$cells (Ji et al., 2005) and adoptive transfer of Tregs also reduced disease development significantly. On the other hand, mice chronically infected with L. major showed disease reactivation upon transfer of Tregs whereas depletion of $\mathrm{CD} 25^{+}$cells at the time of reinfection prevented this outcome (Mendez et al., 2004). These data suggest an important equilibrium between Treg and effector lymphocytes in controlling both immunological recall responses and disease reactivation.

In the present work, we have evaluated the presence of Tregs during experimental $L$. braziliensis infection. BALB/c mice inoculated intradermally with $L$. braziliensis provide a good correlate of human CL as parasite expansion at the infection site is controlled by a cellular immune response that also mediates the development of an ulcer (de Moura et al., 2005). Notably, in this model the localized dermal lesion heals spontaneously but parasites persist within the dLN, indicating the existence of regulatory or suppressive immune mechanisms. We characterized $\mathrm{CD} 4^{+} \mathrm{CD} 25^{+}$cells present during the course of disease in terms of phenotype and function. We also investigated the outcome of an experimental reinfection in the context of an existing regulatory response.

\section{Materials and methods}

\subsection{Mice and ethics statement}

Female BALB/c mice were obtained from the Centro de Pesquisas Gonçalo Moniz/Fundação Oswaldo Cruz Animal Facility, Brazil. All mice were maintained under pathogen-free conditions and were employed in experiments at 6-8 weeks of age. Experiments were performed twice or three times with groups of five to six mice, using methods approved by the Animal Care and Utilization Committee from Centro de Pesquisas Gonçalo Moniz/Fundação Oswaldo Cruz (Approval ID: L-14/09). 

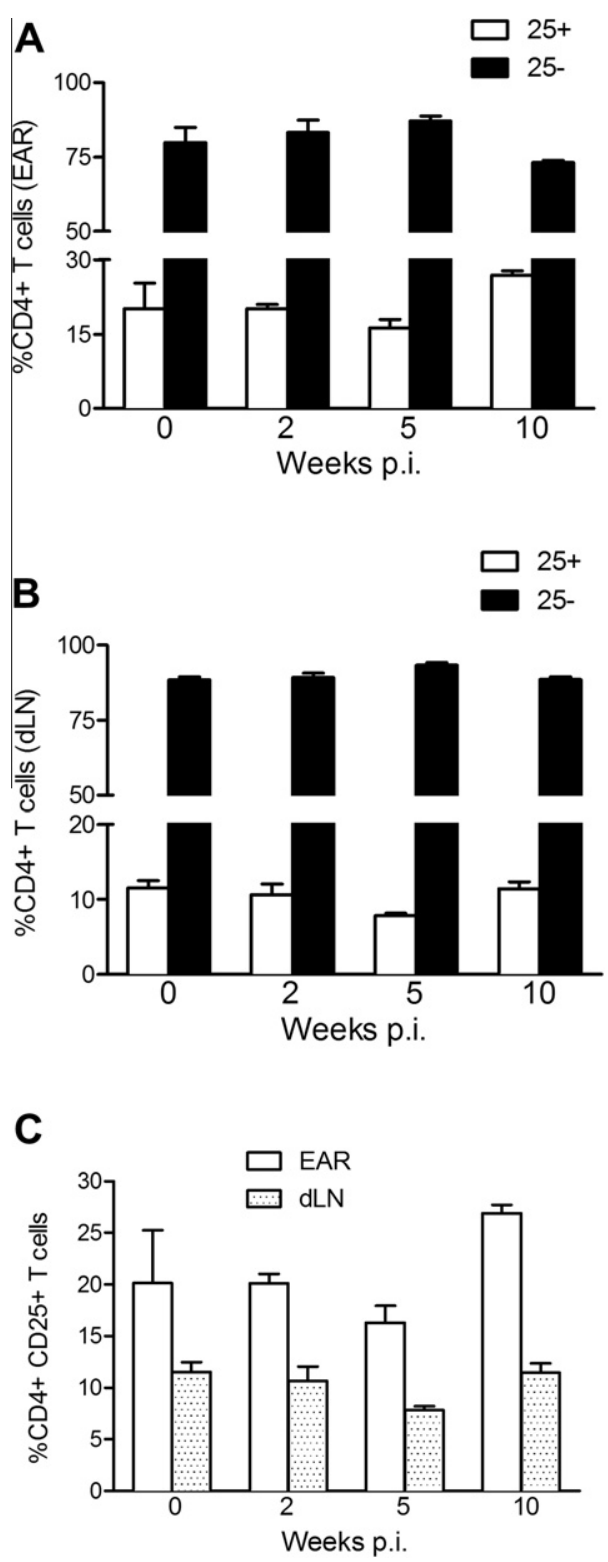

Fig. 2. $\mathrm{CD} 4^{+} \mathrm{CD} 25^{+} \mathrm{T}$ cells in the ears and draining lymph nodes (dLNs) of mice infected with Leishmania braziliensis. BALB/c mice were infected in the dermis of the ear with $10^{5} \mathrm{~L}$. braziliensis promastigotes. Mice were euthanized at time zero, 2, 5 and 10 weeks p.i.; then ears and dLNs were pooled, stained and the percentage of $\mathrm{CD} 4^{+} \mathrm{CD} 25^{+} \mathrm{T}$ cells determined by flow cytometry. Percentages of CD25 $5^{+}$and $\mathrm{CD} 25^{-}$ $\mathrm{CD} 4^{+} \mathrm{T}$ cells in ears (A) and dLNs (B) are shown. (C) Comparison of $\mathrm{CD}^{+} \mathrm{CD} 25^{+} \mathrm{T}$ cells between ears and dLNs. The data shown (mean \pm S.E.M.) and $P$ values are from a single experiment, performed with six mice, representative of three independent experiments that provided similar results.

\subsection{Parasite culture}

Leishmania braziliensis (strain MHOM/BR/01/BA788) (de Moura et al., 2005) promastigotes were grown in Schneider medium (Sigma, USA) supplemented with $100 \mathrm{U} / \mathrm{ml}$ of penicillin, $100 \mathrm{mg} / \mathrm{ml}$ of streptomycin and 10\% heat-inactivated FCS (all from Invitrogen, USA).

\subsection{Intradermal inoculation, evaluation of parasite load and lesion measurement}

BALB/c mice were infected with stationary-phase $L$. braziliensis promastigotes ( $10^{5}$ parasites in $10 \mu \mathrm{l}$ of saline), inoculated into the right ear dermis using a 27.5 gauge needle. At different times (2, 5 and 10 weeks) following $L$. braziliensis infection, mice were euthanized and parasite loads were determined using a quantitative limiting-dilution assay as described previously (de Moura et al., 2005). Lesion development was monitored on a weekly basis using a digital caliper (Thomas Scientific USA) A group of healed $\mathrm{BALB} / \mathrm{c}$ mice was reinfected in the opposite ear, 10 weeks after the initial parasite inoculation, at the time of lesion healing. A control group of healed mice was not reinfected and was maintained for the same time period. In parallel, another group of five naïve $\mathrm{BALB} / \mathrm{c}$ mice was infected in order to monitor for parasite infectivity.

\subsection{Phenotypic characterization of T cells by flow cytometry}

Mice were infected with $L$. braziliensis promastigotes as described in Section 2.3. At different times following $L$. braziliensis infection, mice were euthanized and a single cell suspension of the dLN and the infected ear were prepared aseptically. Briefly, LNs were homogenized in RPMI Medium and cells were resuspended in RPMI supplemented with $2 \mathrm{mM}$ L-glutamine, $100 \mathrm{U} / \mathrm{ml}$ of penicillin, $100 \mu \mathrm{g} / \mathrm{ml}$ of streptomycin, 10\% FCS (all from Invitrogen), and $0.05 \mathrm{M} 2$-mercaptoethanol. The ventral and dorsal sheets of the infected ears were separated and incubated for $1 \mathrm{~h}$ at $37^{\circ} \mathrm{C}$, $5 \% \mathrm{CO}_{2}$ in RPMI medium containing Liberase $\mathrm{CI}$ enzyme blend $(50 \mu \mathrm{g} / \mathrm{ml})$ (Roche, USA). Ears were processed using a Medimachine (Becton Dickinson, USA) and cell suspensions were washed by centrifugation. Cells were blocked with anti-Fc receptor antibody (2.4 G2) and stained with anti-mouse CD4-FITC (BD Pharmingen, USA) and CD25 Cy-Chrome (BD Pharmingen), and either Rphycoerythrin (PE) anti-GITR or PE anti-CD103 (all from BD Pharmingen). For intracellular staining of Foxp3, cells were permeabilized using Cytofix/Cytoperm (BD Biosciences, USA) and were incubated with PE anti-Foxp3 (Ebioscience, USA). Reinfected mice were probed for the presence of Foxp $3^{+}$cells and for cytokine-secreting $\mathrm{CD}^{+} \mathrm{T}$ cells, as described elsewhere (de Moura et al., 2005). Briefly, cells were activated in the presence of anti-CD3 $(10 \mu \mathrm{g} / \mathrm{ml})$ and anti-CD28 $(10 \mu \mathrm{g} / \mathrm{ml})$ and were later incubated with Brefeldin A (Sigma) $(10 \mu \mathrm{g} / \mathrm{ml})$. Cells were permeabilized using Cytofix/Cytoperm (BD Biosciences) and were incubated with anti-cytokine antibodies conjugated to PE: IFN- $\gamma$ or IL-10 (BD Biosciences). The isotype controls used were rat IgG2b and rat IgG2a 9 (BD Biosciences). Data were collected and analyzed using a FACSort ${ }^{\circledR}$ flow cytometer and CELLQuest ${ }^{\mathrm{TM}}$ software (Becton Dickinson Immunocytometry System). The steady-state frequencies of cytokine positive cells were determined using LN cells from PBS-inoculated mice.

\subsection{Purification of $T$ cell subsets and in vitro stimulation}

$\mathrm{CD}^{+} \mathrm{T}$ cells were purified from the dLNs of infected mice by negative selection using magnetic beads $\left(\mathrm{CD} 4^{+} \mathrm{CD} 25^{+}\right.$Regulatory $\mathrm{T}$ cell isolation kit, Miltenyi Biotech, Germany), following the manufacturer's instructions. Briefly, mice were infected with $L$. braziliensis promastigotes, then at 2 and 5 weeks p.i., mice were euthanized and single cell suspensions from the dLNs were obtained as described in Section 2.4. For the isolation of $\mathrm{CD}^{+} \mathrm{T}$ cells by negative selection, non-CD4 ${ }^{+} \mathrm{T}$ cells were indirectly magnetically labeled with a cocktail of biotin-conjugated antibodies and anti-biotin microbeads. Magnetic separation was performed using a MACS separation column. The resulting $\mathrm{T}$ cells were labeled with anti-CD25 PE and further purified using magnetically labeled antiPE microbeads and a fresh MACS separation column to obtain $\mathrm{CD} 4^{+} \mathrm{CD} 25^{+} \mathrm{T}$ cells. Purities of the $\mathrm{CD} 4^{+} \mathrm{CD} 25^{+}$and $\mathrm{CD} 4^{+} \mathrm{CD} 25^{-} \mathrm{T}$ cell populations were determined by flow cytometry and were routinely above $90 \%$ and $95 \%$, respectively. The two sub-populations 


\section{EAR}

A

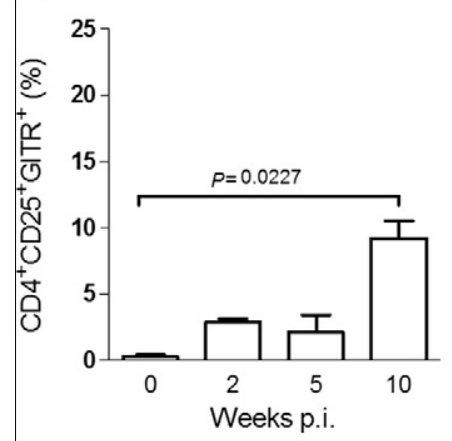

\section{dLN}

D

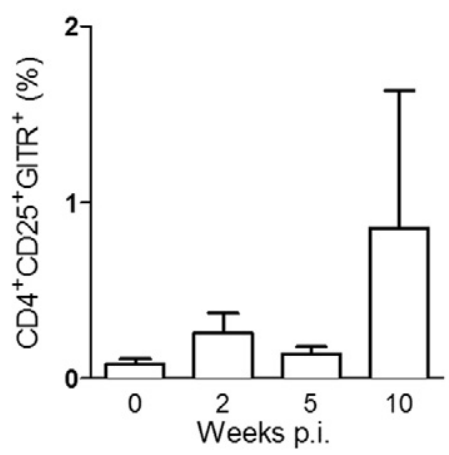

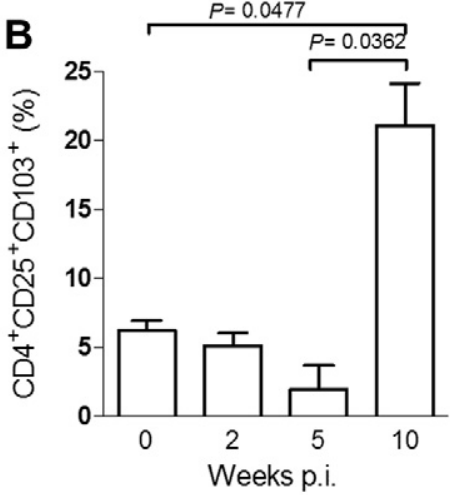

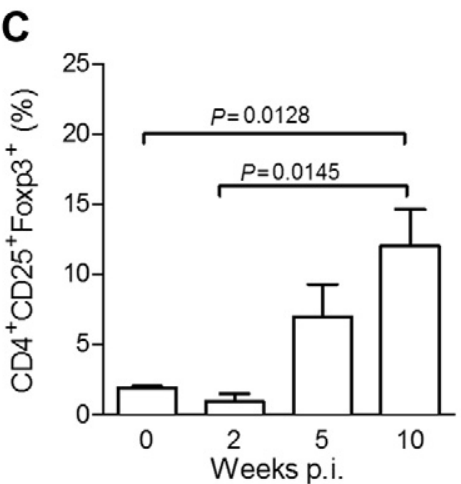

E

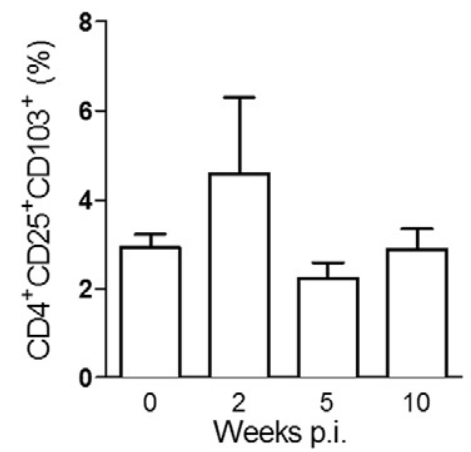

$\mathbf{F}$

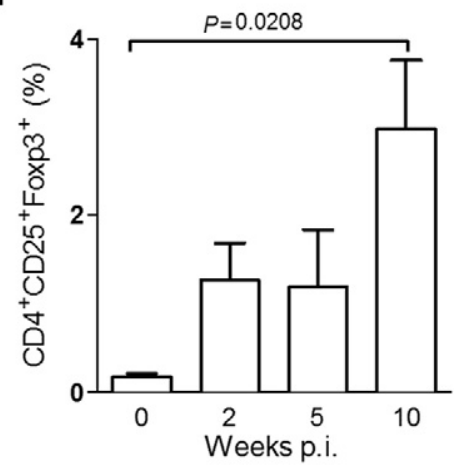

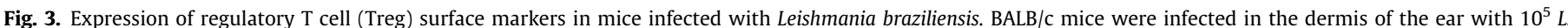

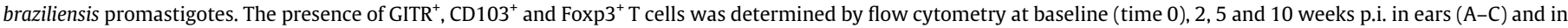

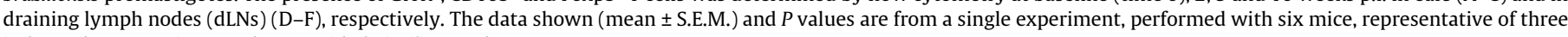
independent experiments that provided similar results.

were cultured in the presence of anti-CD3 $(10 \mu \mathrm{g} / \mathrm{ml})$ and antiCD28 $(10 \mu \mathrm{g} / \mathrm{ml})$ for 4 days in 96 -well, round bottomed plates. One $\mu \mathrm{Ci}$ of $[3 \mathrm{H}]$ Thymidine was added $18 \mathrm{~h}$ before harvest and incorporated radioactivity was determined on a beta emission reader.

\subsection{Statistical analysis}

The data are presented as the mean \pm S.E. of the mean. The significance of the results was calculated using non-parametrical statistical tests: Mann-Whitney (a non-parametric test that compares the distributions of two unmatched groups), for comparisons between two groups, or Kruskal-Wallis, followed by Dunn's multiple comparison test, for comparisons between three groups. Analyses were conducted using Prism (GraphPad software) and $P<0.05$ was considered significant.

\section{Results}

\subsection{Leishmania braziliensis infection and expansion of $C D 4^{+} C D 25^{+} T$ cells}

Following inoculation of $L$. braziliensis into the ear dermis of $\mathrm{BALB} / \mathrm{c}$ mice, parasite multiplication increased steadily from weeks 2 to 5 (Fig. 1A) and then decreased by week 10 . These results paralleled the changes in ear thickness, which represented lesion development and healing (Fig. 1B) as reported previously (de
Moura et al., 2005). In the dLN from the infection site, parasite load increased significantly from weeks $2-5$, paralleling lesion development, and remained high after healing (Fig. 1C). Interestingly, the dLN also displayed a significant increase in total cellularity following infection with L. braziliensis (Fig. 1D).

\subsection{Characterization of Tregs following L. braziliensis inoculation}

Initially, the dynamics of $\mathrm{CD} 4^{+} \mathrm{CD} 25^{+} \mathrm{T}$ cell presence following $L$. braziliensis infection was determined by flow cytometry (Supplementary Fig. S1). At both the ear dermis (Fig. 2A) and in the dLN (Fig. 2B), the percentage of $\mathrm{CD} 4^{+} \mathrm{CD} 25^{+} \mathrm{T}$ cells was constantly lower compared with $\mathrm{CD} 4^{+} \mathrm{CD} 25^{-} \mathrm{T}$ cells when examined at baseline (time 0), 2, 5 and 10 weeks post-parasite inoculation. Starting at baseline (time 0 ) and maintained throughout the evaluation period, a higher frequency of $\mathrm{CD} 4^{+} \mathrm{CD} 25^{+} \mathrm{T}$ cells at the ear when compared with dLNs was observed (Fig. 2C), albeit this difference was not significant at any of the time points evaluated.

We next determined the percentages of $\mathrm{CD}^{+} \mathrm{CD} 25^{+} \mathrm{T}$ cells expressing the Treg markers GITR, CD103 and Foxp3 at both the infection site and in the dLN. In the ear dermis, $\mathrm{CD} 4^{+} \mathrm{CD} 25^{+} \mathrm{T}$ cells positive for GITR (Fig. 3A), CD103 (Fig. 3B) or Foxp3 (Fig. 3C) were detected at all time points evaluated. Notably, the percentage of $\mathrm{CD}^{+} \mathrm{CD} 25^{+}$cells expressing either $\mathrm{GITR}^{+}$(Fig. 3A), CD103 (Fig. 3B) or Foxp $3^{+}$(Fig. 3C) was significantly higher at 10 weeks p.i. compared with baseline levels (time 0 ). At 10 weeks, lesion healing was observed and ear thickness had returned to baseline 

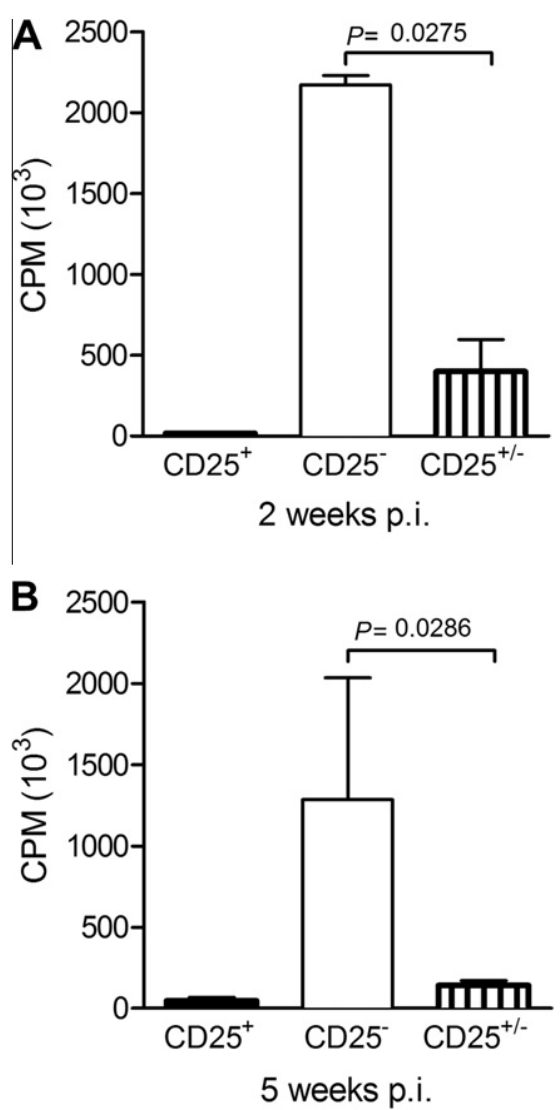

Fig. 4. Suppression of $\mathrm{CD} 4^{+} \mathrm{CD} 25^{-} \mathrm{T}$ cell proliferation by $\mathrm{CD} 4^{+} \mathrm{CD} 25^{+} \mathrm{T}$ cells. BALB/c mice were infected in the dermis of the ear with $10^{5}$ Leishmania braziliensis promastigotes. $\mathrm{CD} 4^{+} \mathrm{CD} 25^{+}$and $\mathrm{CD} 4^{+} \mathrm{CD} 25^{-}$T cells were obtained from the draining lymph nodes (dLNs) at 2 (A) or 5 (B) weeks p.i., isolated, then either cultured alone or co-cultured at a 1:1 ratio for 5 days. Proliferation was induced by anti-CD3 plus anti-CD28. The data shown (mean \pm S.E.M.) and $P$ values are from a single experiment, performed with six mice, representative of two independent experiments that provided similar results.

(Fig. 1B). In the dLN, the overall percentage of $\mathrm{CD} 4^{+} \mathrm{CD} 25^{+} \mathrm{T}$ cells expressing the surface markers analyzed was $\sim$ fivefold lower (Fig. 3D and E), compared with the frequency found in the ear dermis (Fig. 3A-C). Moreover, the frequency of $\mathrm{CD} 4^{+} \mathrm{CD} 25^{+} \mathrm{Foxp}^{+} \mathrm{T}$ cells at 10 weeks p.i. was also significantly higher (Fig. $3 F$ ) compared with baseline levels (time 0), as seen in the ear (Fig. 3C). Therefore, at 10 weeks, Foxp $3^{+}$cell accumulation at the infection site (ear) paralleled controls in parasite multiplication (Fig. 1A) and lesion healing (Fig. 1B). In the dLN, Foxp $3^{+}$cell accumulation at 10 weeks p.i. reflected parasite maintenance (Fig. 1C). Upon stimulation with anti-CD3 and anti-CD28, CD4 ${ }^{+} \mathrm{CD} 25^{+} \mathrm{T}$ cells obtained from dLNs at 2 and 5 weeks p.i. showed minimal proliferation compared with $\mathrm{CD} 4^{+} \mathrm{CD} 25^{-} \mathrm{T}$ cells (Fig. $4 \mathrm{~A}$ and $\mathrm{B}$, respectively). Co-culture of $\mathrm{CD} 4^{+} \mathrm{CD} 25^{+}$and $\mathrm{CD} 4^{+} \mathrm{CD} 25^{-} \mathrm{T}$ cells significantly suppressed $\mathrm{CD} 4^{+} \mathrm{CD} 25^{-} \mathrm{T}$ cell proliferation, indicating that the $\mathrm{CD}^{+} \mathrm{CD} 25^{+} \mathrm{T}$ cell subset isolated following $L$. braziliensis infection had a regulatory phenotype.

\subsection{Lack of disease reactivation following reinfection of healed mice}

The preceding experiments had demonstrated the presence of a regulatory immune response in BALB/c mice infected with $L$. braziliensis. Therefore, we next investigated the outcome of a reinfection with $L$. braziliensis, after lesion healing (Fig. 5). Ten weeks after the initial infection, a group of healed mice was reinfected with $L$. braziliensis in the contralateral ear and lesion development was monitored for another 10 weeks (healed + reinfected mice) (Fig. 5A). Another group of healed mice remained uninfected and acted as controls (healed mice) (Fig. 5A). A third group of naïve mice was inoculated with the same parasite preparation, to monitor for parasite virulence and was also evaluated over the same time period (naive mice) (Fig. 5A). As anticipated, a lesion developed at the ear dermis at 5 weeks p.i. and healed at 10 weeks (Fig. 5B). When healed mice were re-infected at a secondary site, we did not observe any increase in ear thickness at the primary site throughout the following observation period (Fig. 5B, shaded area). Moreover, no development of a new lesion nor an increase in ear thickness at the secondary site, where re-infection occurred was observed (Fig. 5C), suggesting the existence of protective immunity against a new parasite challenge. Interestingly, 5 weeks after reinfection ( 15 weeks after the initial infection) parasites were not detected at the secondary infection site (contralateral ear), in the group of healed + reinfected mice (data not shown). Control naïve mice, on the other hand, each developed a lesion that peaked at 5 weeks p.i. and was cured by 10 weeks p.i. (Fig. 5D).

Five weeks after reinfection (equivalent to 15 weeks after the initial infection), the presence of Tregs $\left(\mathrm{CD} 4^{+} \mathrm{CD} 25^{+} \mathrm{Foxp}^{+}\right)$in both groups of mice was analyzed: healed and healed + reinfected. This time point was chosen based on the natural course of infection with $L$. braziliensis, when parasite multiplication at the infection site is maximal as is lesion size (Fig. 1A and B). In these experiments, the primary infection site was evaluated, comparing healed mice and healed + re-infected mice. In the ear (primary site), the percentage ofCD $4^{+} \mathrm{CD} 25^{+} \mathrm{Foxp} 3^{+} \mathrm{T}$ cells was significantly higher in healed mice compared the healed + reinfected group (Fig. 6A). In the corresponding dLN no significant differences between either group of mice was observed (Fig. 6B). Of note, in the group of healed mice, the percentage of $\mathrm{CD} 4^{+} \mathrm{CD} 25^{+} \mathrm{Foxp} 3^{+} \mathrm{T}$ cells detected at 10 weeks (Fig. 3C) in the ear was similar to the percentage obtained at 15 weeks (Fig. 6A), suggesting maintenance of a constant population of Treg cells at the healed site.

We next focused on the group of healed + reinfected mice, comparing differences at the primary versus the secondary site of parasite inoculation (Fig. 7). In this group, no lesion reactivation was detected (primary site) (Fig. 5B) nor development of a new lesion at the contralateral ear (secondary site) (Fig. 5C). In fact, tissue sections obtained 5 weeks after the secondary parasite inoculation showed normal morphology for both the primary (Fig. 7A) and secondary sites of parasite inoculation (Fig. 7B). As stated above, parasites were not detected at the secondary site of parasite inoculation at this time point (data not shown). In terms of Treg distribution, a significantly higher percentage of $\mathrm{CD} 4^{+} \mathrm{CD} 25^{+} \mathrm{Foxp} 3^{+}$ $\mathrm{T}$ cells was found at the primary infection site compared with the secondary infection site (Fig. 7C). Indeed, this outcome was similar to that observed when the primary site of the two groups of mice was compared: healed versus healed + reinfected (Fig. 6A).

\subsection{Parasite load and cytokine production in $d L N$ of healed + reinfected mice}

The healed + reinfected mouse group showed immunity against the development of a new lesion (Figs. 5B and 7B) and parasites were not detected in the contralateral ear (secondary site) (data not shown). As somewhat expected, the parasite load in this group was significantly higher in the LN draining the primary site compared with the LN draining the secondary infection site (Fig. 8A). Nonetheless, the presence of parasites at the LN draining the secondary site indicates that reinfection occurred. On the other hand, this significant difference in parasite load was not accompanied by the presence of Tregs, as $\mathrm{CD} 4^{+} \mathrm{CD} 25^{+} \mathrm{Foxp}^{+} \mathrm{T}$ cells were equally detected within the LNs draining the primary and the secondary sites (Fig. 8B), as were $\mathrm{CD} 4^{+} \mathrm{IL}-10^{+}$cells (Fig. 8C). However, the LN 
A
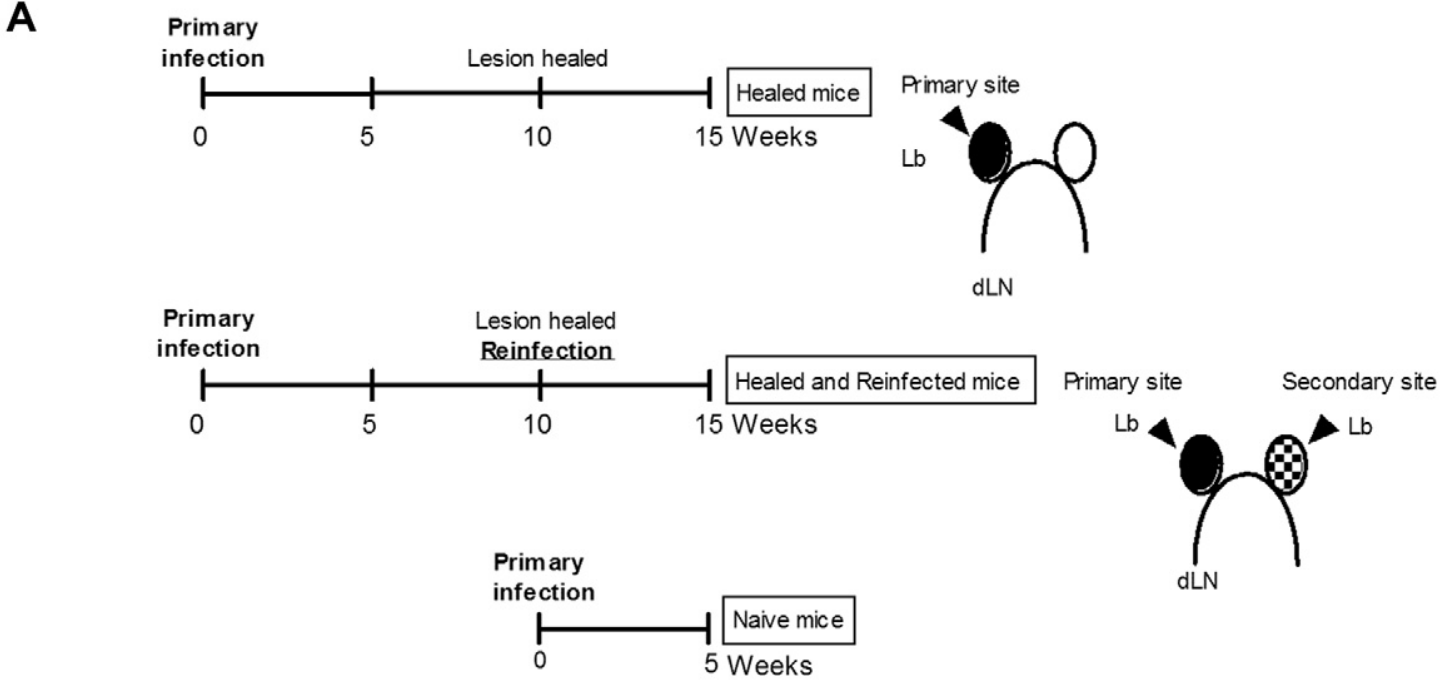

LN
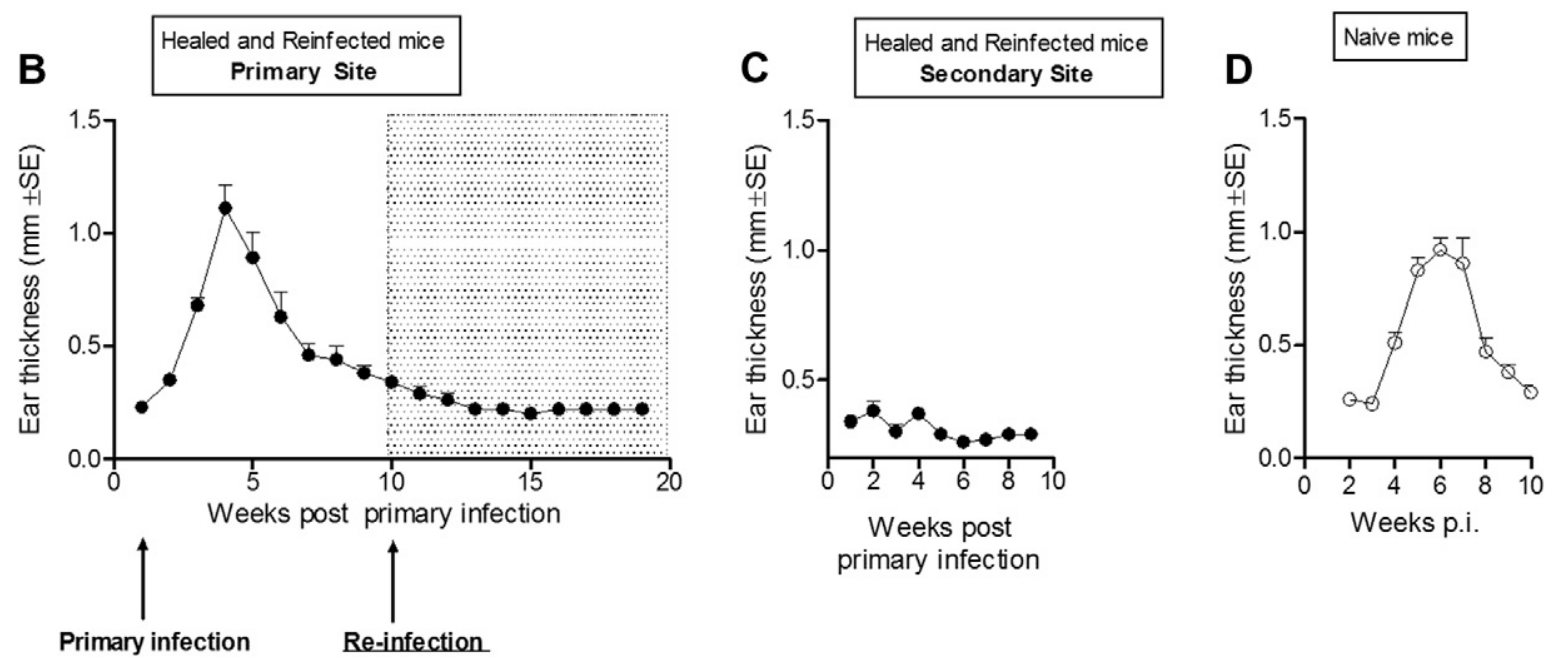

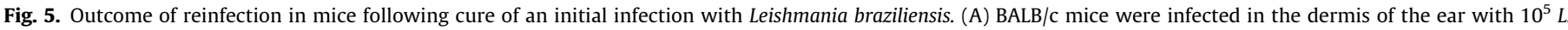

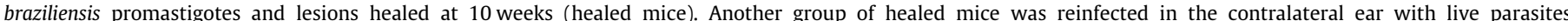

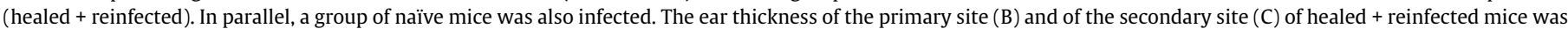

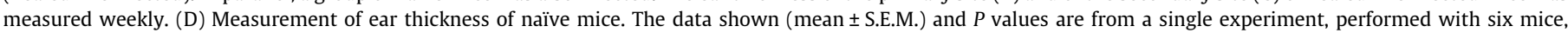
representative of two independent experiments that provided similar results. Lb, Leishmania braziliensis; dLN, draining lymph node.

draining the primary site showed a significantly higher percentage of $\mathrm{CD}^{+} \mathrm{IFN}-\gamma^{+}$cells (Fig. 8D). Therefore, the healed + reinfected group continued to harbor a higher parasite load at the LN draining the primary site, accompanied by a higher frequency of $\mathrm{CD} 4^{+}$IFN- $\gamma^{+}$ cells. Importantly, these mice were immune to a secondary infection.

\section{Discussion}

Natural Tregs were first described in the context of limiting immune-mediated pathology (reviewed in Sakaguchi, 2004). For example, Tregs control self-reactive $\mathrm{T}$ cells in mouse models of colitis, minimizing tissue damage (Powrie et al., 2003). During microbial infections, Tregs can monitor the host's sustained immune response and prevent detrimental effects. In this context Tregs have been shown to limit immunopathology in models of Schistosoma (Hesse et al., 2004), Helicobacter hepaticus (Kullberg et al., 2002), and Pneumocystis carinii (Hori et al., 2002) infections. However, an important consequence of the regulatory role played by Tregs is pathogen survival, which is favored by the control of the effector immune response. Therefore, in this study we examined whether Tregs are present during a model L. braziliensis infection in which parasite persistence is observed. Moreover, we also investigated whether the regulatory response favors disease reactivation upon reinfection.

Initially, our earlier finding that following clinical resolution of an initial $L$. braziliensis infection, parasites are not found at the infection site but are maintained within the dLN was confirmed (de Moura et al., 2005). Of note, an expansion in LN cellularity was associated with effective control of $L$. major infection in resistant B6 mice (Hsu and Scott, 2007). In parallel, $\mathrm{CD}^{+} \mathrm{CD} 25^{+} \mathrm{T}$ cells, which represent $5-10 \%$ of the $\mathrm{CD}^{+} \mathrm{T}$ cell population in general, were detected at the infection site and in the dLN. These cells displayed a typical Treg phenotype as based on the expression of GITR, CD103 and Foxp3. Importantly, Tregs in dLNs failed to proliferate in vitro and suppressed proliferation of $\mathrm{CD} 4{ }^{+} \mathrm{CD} 25^{+} \mathrm{T}$ cells. At the time of lesion healing, the frequency of Tregs at the ear (primary infection site) was higher compared with baseline levels, suggesting their role is in local regulation of the inflammatory immune response, possibly leading to cure. This finding could be attributed to the higher expression of CD103 found at the inoculation site, as CD103 has been shown to favor Treg retention (Suffia 


\section{Healed mice}

Primary site

Lb

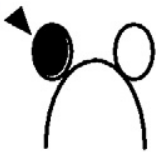

dLN

\section{Healed+Reinfected mice}

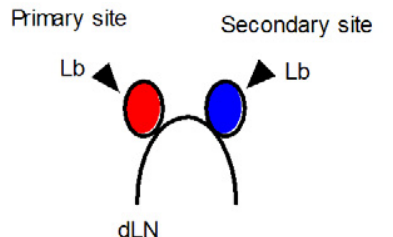

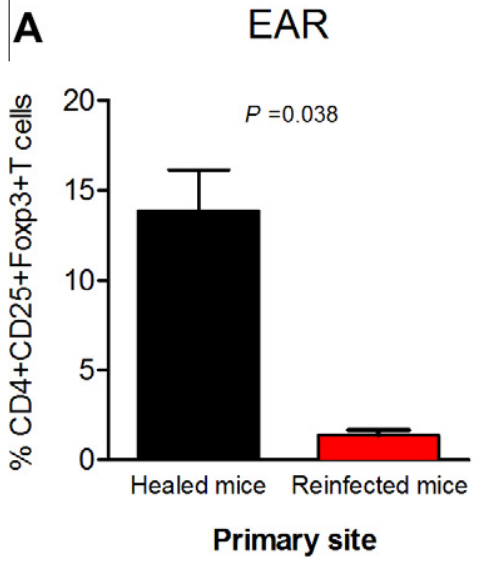

B $\quad \mathrm{dLN}$

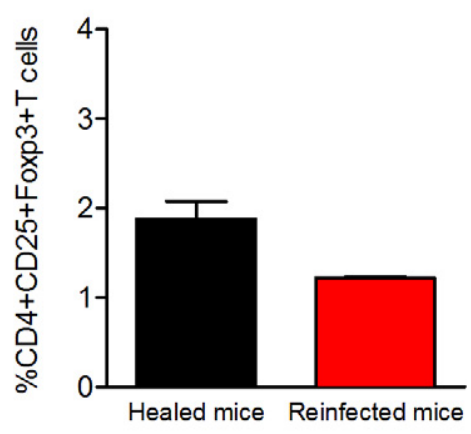

Primary site

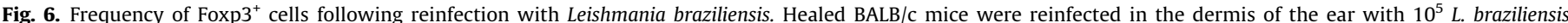

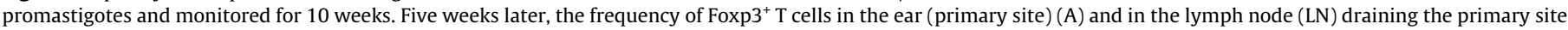

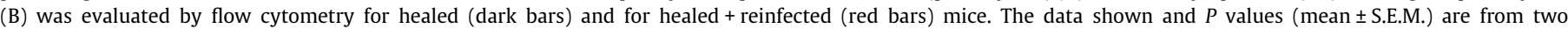
experiments, each performed with six mice, that provided similar results. Lb, L. braziliensis; dLN, draining lymph node.
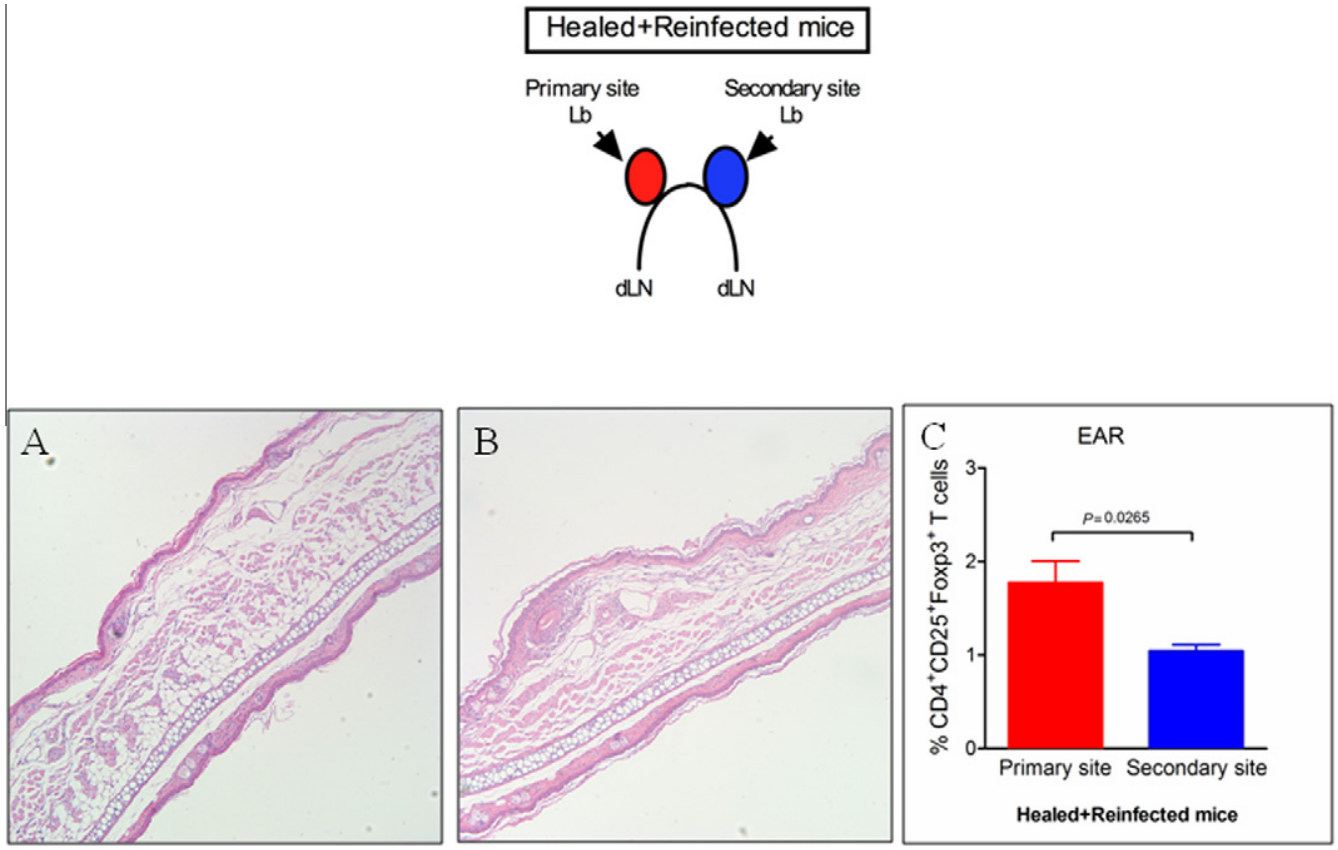

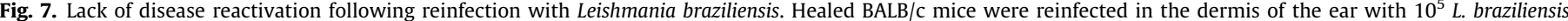

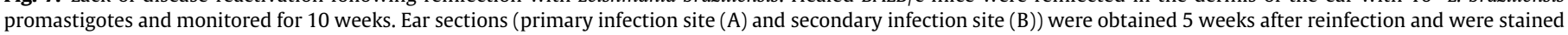

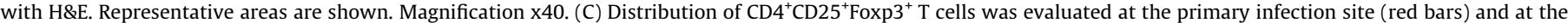

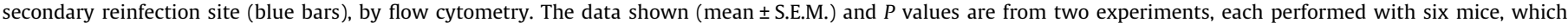
provided similar results. Lb, L. braziliensis; dLN, draining lymph node. 


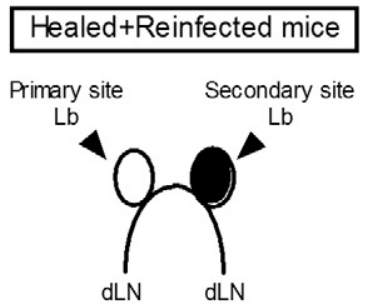

A

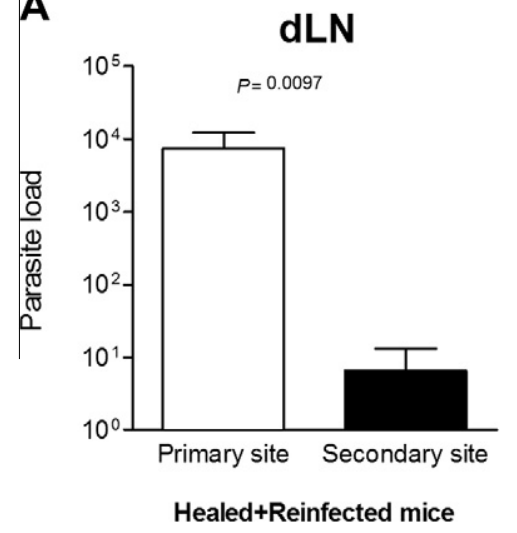

C

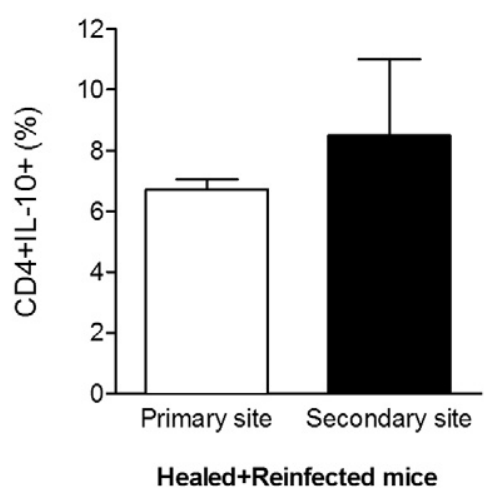

B

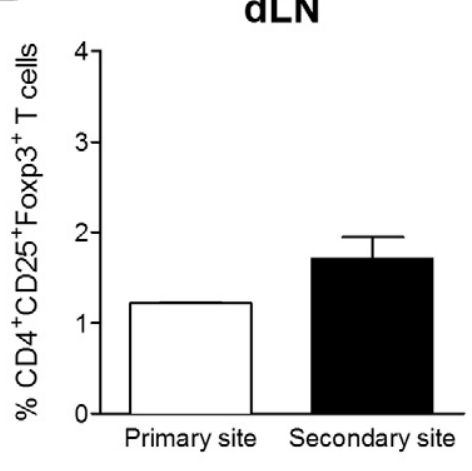

Healed+Reinfected mice
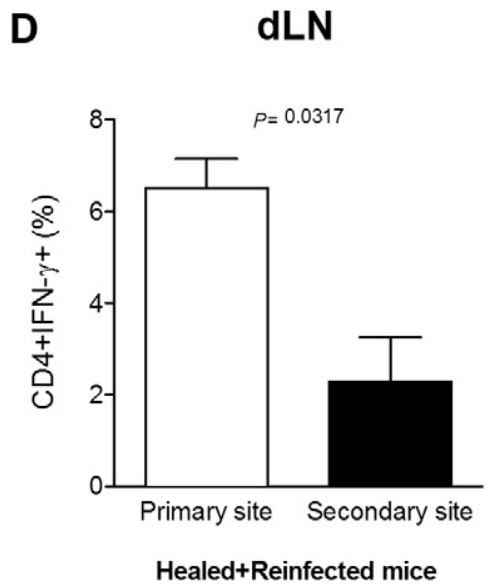

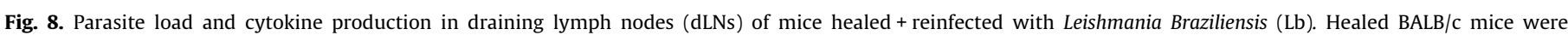

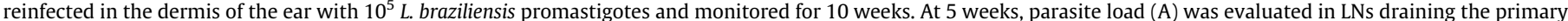

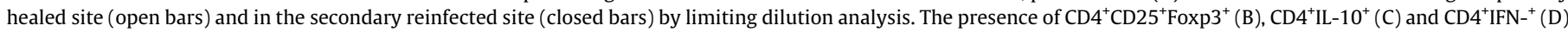

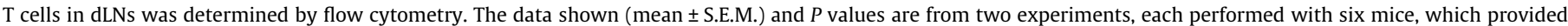
similar results.

et al., 2006). Tregs were also detected in the skin of patients with cutaneous leishmaniasis (Campanelli et al., 2006), indicating that the present experimental setting recapitulates the regulatory response observed during natural infection. Our findings are also in agreement with prior reports showing that L. braziliensis parasites are eliminated from the infection site but persist in the dLN (Rocha et al., 2007; Costa et al., 2011), as do Leishmania chagasi parasites (Rodrigues et al., 2009). It remains to be determined how parasites persist within secondary lymphoid organs.

In experimental leishmaniasis, it is currently unclear whether Tregs are effectively influencing the local immune response in secondary lymphoid organs and, if so, by what means. Upon experimental L. major infection, parasite persistence was associated with the presence of $\mathrm{CD} 4{ }^{+} \mathrm{CD} 25^{+}$Tregs (Belkaid et al., 2002) and antigen-specific $\mathrm{CD} 4^{+} \mathrm{CD} 25^{+}$Tregs were found to produce IL-10, necessary for parasite persistence after clinical cure (Suffia et al., 2006). IL-10 is a cytokine known to down-modulate inflammatory reactions, and the absence of IL-10 can result in efficient clearing of pathogenic infections including Leishmania (Murray and Nathan, 1999; Belkaid et al., 2001; Kane and Mosser, 2001). A recent report showed that inoculation of killed Leishmania parasites lead to loss of immunity (Okwor and Uzonna, 2009) which was associated with an expansion of IL-10-producing $\mathrm{CD} 4^{+} \mathrm{CD} 25^{+} \mathrm{Foxp}^{+} \mathrm{T}$ cells in the dLN. Herein, we observed that both $\mathrm{CD} 4^{+} \mathrm{Foxp}^{+}$and $\mathrm{CD} 4^{+} \mathrm{IL}-10^{+}$ $\mathrm{T}$ cells are present in the dLNs of mice infected with $L$. braziliensis, however, whether these cells are co-expressing IL-10 and Foxp3 was not determined. Importantly, immunity against reinfection was not compromised, despite the presence of $\mathrm{CD} 4^{+} \mathrm{Foxp} 3^{+}$or of 
$\mathrm{CD}^{+} \mathrm{IL}-10^{+} \mathrm{T}$ cells. IL-10 may also be produced by another cell source, namely $\mathrm{CD}^{2} 5^{-}$Foxp3 $^{-}$cells. In fact, IL-10-secreting $\mathrm{CD}^{2} 5^{-} \mathrm{Foxp}^{-}$cells were found in both experimental (Stager et al., 2006; Rodrigues et al., 2009) and in human (Nylen et al., 2007) visceral leishmaniasis. Of note, $\mathrm{CD} 25^{-}$Foxp $3^{-}$cells were also shown to expand in the context of a highly polarized Th1 response, such as that observed in a non-healing model of CL (Anderson et al., 2007) and following Toxoplasma gondii infection (Jankovic et al., 2007). In these particular settings, such cells also produce IFN- $\gamma$, therefore limiting pathology and, in parallel, promoting immunity. Moreover, we cannot exclude that other suppressive mechanisms could also be associated with parasite persistence. For example, local IDO (indoleamine 2,3 dioxygenase) production in the dLN may inhibit the inflammatory response (Makala et al., 2011). In this sense, during infection with Leishmania guyanensis intralesional IDO and Foxp3 expression has been documented, suggesting a role for IDO in suppression exerted by Tregs (Bourreau et al., 2009). We cannot exclude that in dLNs mechanisms other than those exerted by Tregs may also contribute to maintenance of the parasite load. Further, it has been shown that Leishmania can be harbored within cells that cannot exert antimicrobial activity, such as fibroblasts (Moll et al., 1995; Bogdan et al., 2000).

In $L$. major experimental infection, Tregs were essential for the maintenance of cutaneous infection (Belkaid et al., 2002) and were found to be specific for microbial antigens (Belkaid et al., 2006a). Moreover, rechallenge of chronically infected mice led to reactivation of disease at the primary infection site and this reactivation was associated with the presence of Tregs (Mendez et al., 2004). The association between disease reactivation and Tregs was also found in aged hosts, where Tregs suppressed IFN- $\gamma$ production by effector cells (Lages et al., 2008). Herein, following reinfection with L. braziliensis, we did not observe development of new lesions or parasite multiplication at the secondary site, although parasites were detected at the corresponding $\mathrm{dLN}$. Interestingly, following reinfection with $L$. braziliensis, lesion reactivation at the primary infection site was also not observed. Therefore, in the healed + reinfected mouse group, a higher percentage of Tregs at the primary infection site does not promote lesion reactivation nor does it preclude an efficient recall response to $L$. braziliensis at a distal site. In parallel, we can suggest that infection parasite multiplication and/or lesion development did not occur at the site of reinfection, due to immunity. In this sense, mice infected intradermally with $L$. major plus CPG ODN do not develop dermal lesions and show an early containment of parasite growth when later challenged with live parasites (Belkaid et al., 2002). This effect was associated with IFN $-\gamma^{+}$producing $\mathrm{T}$ cells that rapidly infiltrate the secondary site, leading to clearance of viable parasites after rechallenge (Tabbara et al., 2005). This robust effector response has been recently examined in the context of vaccination (Peters et al., 2009). Indeed, herein $\mathrm{CD} 4^{+} \mathrm{IFN}-\gamma^{+} \mathrm{T}$ cells were detected in the LNs draining the primary and secondary sites of $L$. braziliensis infection, suggesting their prompt participation in response to parasite multiplication. Alternatively, parasite control may result from the presence of a $\mathrm{T}_{\mathrm{CM}}$ cell population that can recirculate through the dLN and differentiate into Th1 effector cells, as described for L. major infection (Colpitts and Scott, 2010).

Collectively, our data show that experimental infection with $L$. braziliensis is associated with the presence of Tregs characterized by GITR, CD103 and Foxp3 expression. These cells exert suppressive functions in vitro and are retained within the site of infection, especially in the ear. Tregs were also detected in dLNs where they may act to limit immune-mediated pathology, as this is also the site of parasite persistence. Following a rechallenge, cured mice display full resistance, indicating that the presence of Tregs does not prevent effector recall responses associated with immunity.

\section{Acknowledgments}

We thank Phillip Scott for comments and suggestions.

\section{Appendix A. Supplementary data}

Supplementary data associated with this article can be found, in the online version, at http://dx.doi.org/10.1016/j.ijpara. 2012. 05.006.

\section{References}

Anderson, C.F., Oukka, M., Kuchroo, V.J., Sacks, D., 2007. CD4(+)CD25(-)Foxp3(-) Th1 cells are the source of IL-10-mediated immune suppression in chronic cutaneous leishmaniasis. J. Exp. Med. 204, 285-297.

Aseffa, A., Gumy, A., Launois, P., MacDonald, H.R., Louis, J.A., Tacchini-Cottier, F., 2002. The early IL-4 response to Leishmania major and the resulting Th2 cell maturation steering progressive disease in BALB/c mice are subject to the control of regulatory $\mathrm{CD} 4^{+} \mathrm{CD} 25^{+} \mathrm{T}$ cells. J. Immunol. 169, 3232-3241.

Belkaid, Y., 2003. The role of $\mathrm{CD} 4(+) \mathrm{CD} 25(+)$ regulatory $\mathrm{T}$ cells in Leishmania infection. Exp. Opin. Biol. Th. 3, 875-885.

Belkaid, Y., Blank, R.B., Suffia, I., 2006a. Natural regulatory T cells and parasites: a common quest for host homeostasis. Immunol. Rev. 212, 287-300.

Belkaid, Y., Hoffmann, K., Mendez, S., Kamhawi, S., Udey, M., Wynn, T., Sacks, D., 2001. The role of interleukin (IL)-10 in the persistence of Leishmania major in the skin after healing and the therapeutic potential of anti-IL-10 receptor antibody for sterile cure. J. Exp. Med. 194, 1497-1506.

Belkaid, Y., Piccirillo, C.A., Mendez, S., Shevach, E.M., Sacks, D.L., 2002. CD4 ${ }^{+}$CD $25^{+}$ regulatory $\mathrm{T}$ cells control Leishmania major persistence and immunity. Nature 420, 502-507.

Belkaid, Y., Sun, C.M., Bouladoux, N., 2006b. Parasites and immunoregulatory T cells. Curr. Opin. Immunol. 18, 406-412.

Bittencourt, A., Barral-Netto, M., 1995. Leishmaniasis. In: Seifert, G., Doerr, W. (Eds), Tropical Pathology, Springer, Berlin, pp. 597-651.

Bogdan, C., Donhauser, N., Doring, R., Rollinghoff, M., Diefenbach, A., Rittig, M., 2000. Fibroblasts as host cells in latent leishmaniosis. J. Exp. Med. 191, 2121-2130.

Bopp, T., Becker, C., Klein, M., Klein-Hessling, S., Palmetshofer, A., Serfling, E., Heib, V., Becker, M., Kubach, J., Schmitt, S., Stoll, S., Schild, H., Staege, M.S., Stassen, M., Jonuleit, H., Schmitt, E., 2007. Cyclic adenosine monophosphate is a key component of regulatory T cell-mediated suppression. J. Exp. Med. 204, 13031310 .

Bourreau, E., Ronet, C., Darcissac, E., Lise, M.C., Sainte Marie, D., Clity, E., TacchiniCottier, F., Couppie, P., Launois, P., 2009. Intralesional regulatory T-cell suppressive function during human acute and chronic cutaneous leishmaniasis due to Leishmania guyanensis. Infect. Immun. 77, 1465-1474.

Campanelli, A.P., Roselino, A.M., Cavassani, K.A., Pereira, M.S., Mortara, R.A., Brodskyn, C.I., Goncalves, H.S., Belkaid, Y., Barral-Netto, M., Barral, A., Silva, J.S., 2006. $\mathrm{CD}^{+} \mathrm{CD} 25^{+} \mathrm{T}$ cells in skin lesions of patients with cutaneous leishmaniasis exhibit phenotypic and functional characteristics of natural regulatory T cells. J. Infec. Dis. 193, 1313-1322.

Collison, L.W., Workman, C.J., Kuo, T.T., Boyd, K., Wang, Y., Vignali, K.M., Cross, R. Sehy, D., Blumberg, R.S., Vignali, D.A., 2007. The inhibitory cytokine IL-35 contributes to regulatory T-cell function. Nature 450, 566-569.

Colpitts, S.L., Scott, P., 2010. The early generation of a heterogeneous CD4 ${ }^{+} \mathrm{T}$ cell response to Leishmania major. J. Immunol. 185, 2416-2423.

Costa, D.L., Carregaro, V., Lima-Junior, D.S., Silva, N.M., Milanezi, C.M., Cardoso, C.R., Giudice, A., de Jesus, A.R., Carvalho, E.M., Almeida, R.P., Silva, J.S., 2011. BALB/c mice infected with antimony treatment refractory isolate of Leishmania braziliensis present severe lesions due to IL-4 production. PLoS Negl. Trop. Dis. 5, e965.

Coutinho, S.G., Pirmez, C., Da-Cruz, A.M., 2002. Parasitological and immunological follow-up of American tegumentary leishmaniasis patients. T. Roy. Soc. Trop. Med. H., S173-S178.

de Moura, T.R., Novais, F.O., Oliveira, F., Clarencio, J., Noronha, A., Barral, A., Brodskyn, C., de Oliveira, C.I., 2005. Toward a novel experimental model of infection to study American cutaneous leishmaniasis caused by Leishmania braziliensis. Infect. Immun. 73, 5827-5834.

Fontenot, J.D., Gavin, M.A., Rudensky, A.Y., 2003. Foxp3 programs the development and function of $\mathrm{CD} 4^{+} \mathrm{CD} 25^{+}$regulatory $\mathrm{T}$ cells. Nat. Immunol. 4, 330-336.

Hesse, M., Piccirillo, C.A., Belkaid, Y., Prufer, J., Mentink-Kane, M., Leusink, M., Cheever, A.W., Shevach, E.M., Wynn, T.A., 2004. The pathogenesis of schistosomiasis is controlled by cooperating IL-10-producing innate effector and regulatory T cells. J. Immunol. 172, 3157-3166.

Hori, S., Carvalho, T.L., Demengeot, J., 2002. CD25+CD4 ${ }^{+}$regulatory T cells suppress $\mathrm{CD}^{+} \mathrm{T}$ cell-mediated pulmonary hyperinflammation driven by Pneumocystis carinii in immunodeficient mice. Eur. J. Immunol. 32, 1282-1291.

Hori, S., Nomura, T., Sakaguchi, S., 2003. Control of regulatory T cell development by the transcription factor Foxp3. Science 299, 1057-1061.

Hsu, A., Scott, P., 2007. Leishmania mexicana infection induces impaired lymph node expansion and Th1 cell differentiation despite normal $\mathrm{T}$ cell proliferation. J. Immunol. 179, 8200 
Jankovic, D., Kullberg, M.C., Feng, C.G., Goldszmid, R.S., Collazo, C.M., Wilson, M., Wynn, T.A., Kamanaka, M., Flavell, R.A., Sher, A., 2007. Conventional Tbet(+)Foxp3(-) Th1 cells are the major source of host-protective regulatory IL-10 during intracellular protozoan infection. J. Exp. Med. 204, 273-283.

Ji, J., Masterson, J., Sun, J., Soong, L., 2005. CD4 ${ }^{+} \mathrm{CD} 25^{+}$regulatory T cells restrain pathogenic responses during Leishmania amazonensis infection. J. Immunol. 174, 7147-7153.

Kane, M.M., Mosser, D.M., 2001. The role of IL-10 in promoting disease progression in leishmaniasis. J. Immunol. 166, 1141-1147.

Khattri, R., Cox, T., Yasayko, S.A., Ramsdell, F., 2003. An essential role for Scurfin in $\mathrm{CD}^{+} \mathrm{CD} 25^{+} \mathrm{T}$ regulatory cells. Nat. Immunol. 4, 337-342.

Kullberg, M.C., Jankovic, D., Gorelick, P.L., Caspar, P., Letterio, J.J., Cheever, A.W., Sher, A., 2002. Bacteria-triggered CD4(+) T regulatory cells suppress Helicobacter hepaticus-induced colitis. J. Exp. Med. 196, 505-515.

Lages, C.S., Suffia, I., Velilla, P.A., Huang, B., Warshaw, G., Hildeman, D.A., Belkaid, Y., Chougnet, C., 2008. Functional regulatory T cells accumulate in aged hosts and promote chronic infectious disease reactivation. J. Immunol. 181, 1835-1848.

Locksley, R.M., Heinzel, F.P., Holaday, B.J., Mutha, S.S., Reiner, S.L., Sadick, M.D., 1991. Induction of Th1 and Th2 $\mathrm{CD}^{+}$subsets during murine Leishmania major infection. Res. Immunol. 142, 28-32.

Makala, L.H., Baban, B., Lemos, H., El-Awady, A.R., Chandler, P.R., Hou, D.Y., Munn, D.H. Mellor, A.L., 2011. Leishmania major attenuates host immunity by stimulating local indoleamine 2,3-dioxygenase expression. J. Infect. Dis. 203, 715-725.

Mendez, S., Reckling, S., Piccirillo, C., Sacks, D., Belkaid, Y., 2004. Role for CD4(+) $\mathrm{CD} 25(+)$ regulatory $\mathrm{T}$ cells in reactivation of persistent leishmaniasis and control of concomitant immunity. J. Exp. Med. 200, 201-210.

Moll, H., Flohe, S., Blank, C., 1995. Dendritic cells seclude Leishmania parasites that persist in cured mice - a role in the maintenance of T-cell memory? Adv. Exp. Med. Biol. 378, 507-509.

Murray, H., Nathan, C., 1999. Macrophage microbicidal mechanisms in vivo: reactive nitrogen versus oxygen intermediates in the killing of intracellular visceral Leishmania donovani. J. Exp. Med. 189, 741-746.

Nylen, S., Maurya, R., Eidsmo, L., Manandhar, K., Sundar, S., Sacks, D., 2007. Splenic accumulation of IL-10 mRNA in T cells distinct from CD4 $4^{+} \mathrm{CD} 25^{+}$(Foxp3) regulatory T cells in human visceral leishmaniasis. J. Exp. Med. 204, 805-817.

Okwor, I., Uzonna, J., 2009. Vaccines and vaccination strategies against human cutaneous leishmaniasis. Hum. Vaccines 5, 230-291.

Pandiyan, P., Zheng, L., Ishihara, S., Reed, J., Lenardo, M.J., 2007. CD $4^{+} \mathrm{CD} 25^{+}$Foxp $3^{+}$ regulatory $\mathrm{T}$ cells induce cytokine deprivation-mediated apoptosis of effector $\mathrm{CD}^{+} \mathrm{T}$ cells. Nat. Immunol. 8, 1353-1362.

Peters, N.C., Kimblin, N., Secundino, N., Kamhawi, S., Lawyer, P., Sacks, D.L., 2009. Vector transmission of Leishmania abrogates vaccine-induced protective immunity. PLoS Pathog. 5, e1000484.
Piccirillo, C.A., Shevach, E.M., 2001. Cutting edge: control of CD8 ${ }^{+} \mathrm{T}$ cell activation by $\mathrm{CD} 4^{+} \mathrm{CD} 25^{+}$immunoregulatory cells. J. Immunol. 167, 1137-1140.

Powrie, F., Read, S., Mottet, C., Uhlig, H., Maloy, K., 2003. Control of immune pathology by regulatory T cells. Novartis Foundat. Sympos. 252, 92-98.

Ramirez, J.L., Guevara, P., 1997. Persistent infections by Leishmania (Viannia) braziliensis. Mem. Inst. Oswaldo Cruz 92, 333-338.

Rocha, F., Schleicher, U., Mattner, J., Alber, G., Bogdan, C., 2007. Cytokines, signaling pathways, and effector molecules required for the control of Leishmania (Viannia) braziliensis in mice. Infect. Immun. i3823-i3832.

Rodrigues, O.R., Marques, C., Soares-Clemente, M., Ferronha, M.H., Santos-Gomes, G.M., 2009. Identification of regulatory T cells during experimental Leishmania infantum infection. Immunobiology 214, 101-111.

Sakaguchi, S., 2004. Naturally arising $\mathrm{CD} 4^{+}$regulatory t cells for immunologic selftolerance and negative control of immune responses. Annu. Rev. Immunol. 22, 531-562.

Sakaguchi, S., Sakaguchi, N., Asano, M., Itoh, M., Toda, M., 1995. Immunologic selftolerance maintained by activated T cells expressing IL-2 receptor alpha-chains (CD25). Breakdown of a single mechanism of self-tolerance causes various autoimmune diseases. J. Immunol. 155, 1151-1164.

Scott, P., Pearce, E., Cheever, A.W., Coffman, R.L., Sher, A., 1989. Role of cytokines and $\mathrm{CD}^{+} \mathrm{T}$-cell subsets in the regulation of parasite immunity and disease. Immunol. Rev. 112, 161-182.

Stager, S., Maroof, A., Zubairi, S., Sanos, S.L., Kopf, M., Kaye, P.M., 2006. Distinct roles for IL-6 and IL-12p40 in mediating protection against Leishmania donovani and the expansion of IL- $10^{+} \mathrm{CD} 4^{+} \mathrm{T}$ cells. Eur. J. Immunol. 36, 1764-1771.

Suffia, IJ., Reckling S.K, Piccirillo, CA Goldszmid, R.S., Belkaid, Y, 2006. Infected site-restricted Foxp $^{+}$natural regulatory $\mathrm{T}$ cells are specific for microbial antigens. J. Exp. Med. 203, 777-788.

Tabbara, K.S., Peters, N.C., Afrin, F., Mendez, S., Bertholet, S., Belkaid, Y., Sacks, D.L. 2005. Conditions influencing the efficacy of vaccination with live organisms against Leishmania major infection. Infect. Immun. 73, 4714-4722.

Takahashi, T., Tagami, T., Yamazaki, S., Uede, T., Shimizu, J., Sakaguchi, N., Mak, T.W. Sakaguchi, S., 2000. Immunologic self-tolerance maintained by CD25(+)CD4(+) regulatory $\mathrm{T}$ cells constitutively expressing cytotoxic $\mathrm{T}$ lymphocyte-associated antigen 4. J. Exp. Med. 192, 303-310.

Tang, Q., Bluestone, J.A., 2008. The Foxp $3^{+}$regulatory $\mathrm{T}$ cell: a jack of all trades, master of regulation. Nat. Immunol. 9, 239-244.

Xu, D., Liu, H., Komai-Koma, M., Campbell, C., McSharry, C., Alexander, J., Liew, F.Y. 2003. $\mathrm{CD} 4^{+} \mathrm{CD} 25^{+}$regulatory T cells suppress differentiation and functions of Th1 and Th2 cells, Leishmania major infection, and colitis in mice. J. Immunol. 170, 394-399. 